\title{
A GIS-based methodology to delineate potential areas for groundwater development: a case study from Kathmandu Valley, Nepal
}

\author{
Vishnu P. Pandey $\cdot$ Sangam Shrestha $\cdot$ \\ Futaba Kazama
}

Received: 5 November 2012/ Accepted: 3 March 2013/Published online: 21 March 2013

(C) The Author(s) 2013. This article is published with open access at Springerlink.com

\begin{abstract}
For an effective planning of activities aimed at recovering aquifer depletion and maintaining health of groundwater ecosystem, estimates of spatial distribution in groundwater storage volume would be useful. The estimated volume, if analyzed together with other hydrogeologic characteristics, may help delineate potential areas for groundwater development. This study proposes a GIS-based ARC model to delineate potential areas for groundwater development; where 'A' stands for groundwater availability, ' $R$ ' for groundwater release potential of soil matrix, and ' $\mathrm{C}$ ' for cost for groundwater development. The model is illustrated with a case of the Kathmandu Valley in Central Nepal, where active discussions are going on to develop and implement groundwater management strategies. The study results show that shallow aquifers have high groundwater storage potential (compared to the deep) and favorable areas for groundwater development are concentrated at some particular areas in shallow and deep aquifers. The distribution of groundwater storage and potential areas for groundwater development are then mapped using GIS.
\end{abstract}

Keywords GIS · Groundwater storage · Groundwater management $\cdot$ Kathmandu Valley $\cdot$ Nepal

V. P. Pandey $(\bowtie) \cdot$ F. Kazama

International Research Center for River Basin Environment (ICRE), University of Yamanashi, 4-3-11, Takeda, Kofu, Yamanashi 400-8511, Japan

e-mail: vishnu.pandey@gmail.com

S. Shrestha

Water Engineering and Management Field of Study, School of Engineering and Technology, Asian Institute of Technology, P.O. Box 4, Klong Luang, Pathumthani 12120, Thailand

\section{Introduction}

Depletion of water levels in aquifers and decline in design yield of wells due to excessive pumping in the absence of adequate knowledge on groundwater availability are becoming a major concern across the globe (Babikar et al. 2005; Kendy et al. 2003; Konikow and Kendy 2005; Pandey et al. 2010; Reddy 2005; Saha et al. 2007; Shah et al. 2000). As a response to the problems, approaches like artificial aquifer recharge, managed aquifer recharge, recharge area protection, and construction of underground storage dams are being discussed and practiced to some extent (e.g., Bouwer 2002; Dillon 2005; Kumar et al. 2008; Mills 2002; Scanlon et al. 2002; Shah et al. 2000; Tuinhof and Heederik 2003). For an effective planning of the activities aimed at recovering aquifer depletion and maintaining the health of groundwater ecosystem, estimates of groundwater storage volume and its spatial distribution could be useful. The estimated volume, if analyzed together with other hydrogeologic characteristics, may help delineate potential areas for groundwater development. The development in this paper refers to groundwater extraction. Such estimates could further be used for planning conjunctive use and developing management interventions aimed at sustainable use of the groundwater resources.

Estimating groundwater storage dynamics requires a three-dimensional numerical modeling of a groundwater system that demands advanced knowledge and expertise. However, acceptable estimate of static groundwater storage could be made with relatively fewer resources using readily available secondary data, information and geographic information system (GIS) tool(s). GIS and GIS-based tools are widely used in groundwater studies to analyze and visualize results of groundwater vulnerability (e.g., Kattaa et al. 2010; Nobre et al. 2007; Pathak et al. 2009), groundwater storage

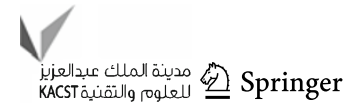


potential (e.g., Singh and Prakash 2002; Wahyuni et al. 2008), groundwater flow and contaminant transport modeling (e.g. Akbar et al. 2011; Chenini and Mammou 2010), among others. Because of the strengths of the GIS techniques in terms of analysis and visualization, some studies have used it as a tool to estimate and map groundwater storage potentials for management purposes (e.g., Johnson and Njuguna 2002; Jorcin 2006; Singh and Prakash S 2002; Wahyuni et al. 2008).

The GIS-based studies made estimates of static groundwater storage volumes; however, did not shed light on further applicability of the results in delineating potential areas for groundwater development. On the other hand, existing approaches for the delineation are based either on a single indicator that may not be adequate to reflect several aspects of groundwater development or on too many indicators, data of which may not readily available for a target area. For example, the existing methods are based on the length of screened sections in the aquifer (Kharel et al. 1998), groundwater storage volume (as estimated in Johnson and Njuguna 2002; Jorcin 2006; Wahyuni et al. 2008), hydrogeology and existing bore wells characteristics (Puranik and Salokhe 2006), multi-parameter data on groundwater (comprising of land use, hydrogeomorphology (e.g., land form, lineaments, drainage density, slope), lithology, soil, rainfall, water level, aquifer thickness, permeability, suitability of groundwater for drinking and irrigation) measured either in field or from remote sensing (Jaiswal et al. 2003; Krishnamurthy et al. 1996; Murthy 2000; Ravi Shankar and Mohan 2006; Saha et al. 2010; Shrinivasa Rao and Jugran 2003). In addition, cost factors are not considered in those studies. Therefore, there is need of a method that can delineate the potential areas from a reasonable number of logically relevant hydrogeologic parameters. The objective of this paper is to propose a simple GIS-based method to delineate potential areas for groundwater development considering groundwater availability (A), groundwater release potential of soil matrix $(\mathrm{R})$, and cost for groundwater extraction (C). In the proposed method, several parameters related to groundwater availability used in the earlier approaches are represented by a single parameter 'groundwater resources availability (A)' and the component is measured by an 'estimated groundwater storage volume', thus reducing greatly the number of parameters to be used in the analysis. The proposed method is termed as an ARC model and is illustrated with a case study of Kathmandu Valley, located in Central Nepal.

\section{Materials and methods}

\section{Development of ARC model}

The GIS-based ARC model was proposed after a thorough review of existing approaches being used for the purpose.
After analyzing the drawbacks of existing approaches (please see the third paragraph of "Introduction" section), the need for a relatively simple method that uses reasonably minimum number of hydrogeologic parameters was realized. Based on the need, available literature on the areas were reviewed, analyzed and synthesized. Finally, three components for the model and one indicator for each of the components were proposed. The procedure is well depicted in Fig. 1. Details of the components and indicators are discussed hereunder.

\section{Model components and indicators}

The ARC model consists of three components-availability of groundwater resources (A), groundwater release potential of soil matrix $(\mathrm{R})$, and cost for groundwater extraction (C). Each components (i.e., A, R and C) of the model in this study are represented by the following indicators-(1) estimated groundwater storage volume for 'A'; (2) hydraulic conductivity for ' $R$ '; and (3) depth of center of aquifer layer below ground level as a proxy for ' $\mathrm{C}$ '. In contrast to the existing methods, the proposed one uses a single component 'groundwater resources availability (A)' to represent several indicators related to groundwater availability, thus, reducing greatly the number of parameters to be used in delineating the potential areas. Also, cost factors are incorporated using a proxy indicator.

\section{Input data (indicator values) preparation}

Three input data (indicator values) representing the three components (i.e., A, R and C) were prepared in GIS following the procedure discussed hereunder. The procedure is depicted in Fig. 2.

Estimation of groundwater storage volume The 'groundwater storage volume' in this study refers to the amount of groundwater that can theoretically be extracted if the shallow aquifer was completely drained or the deep aquifer was extracted to an environmentally safe level. For calculating the volume, spatial distribution of the three parameters-the aquifer thickness, storage coefficient (called as specific yield, $S_{\mathrm{y}}$, in case of the shallow aquifer) and grid surface area-needs to be estimated/calculated as shown in Fig. 2. After that, the raster calculator in ArcGIS can be used as a tool to calculate the volume.

Delineation of thicknesses of hydrogeologic layers is described in Pandey and Kazama (2011). It was based on 112 borehole data (locations are shown in Fig. 3a), which were reclassified in terms of aquifer layers using spatial interpolation techniques in ArcGIS. The reclassification of lithological information (e.g., sand, gravel, clay, etc.) in each borehole were made in terms of shallow aquifer, 
Fig. 1 A schematic diagram depicting procedures of model development, application and output. GWD is groundwater development; $A$ is availability of groundwater resources; $R$ is groundwater release potential of soil matrix; $C$ is cost for groundwater extraction
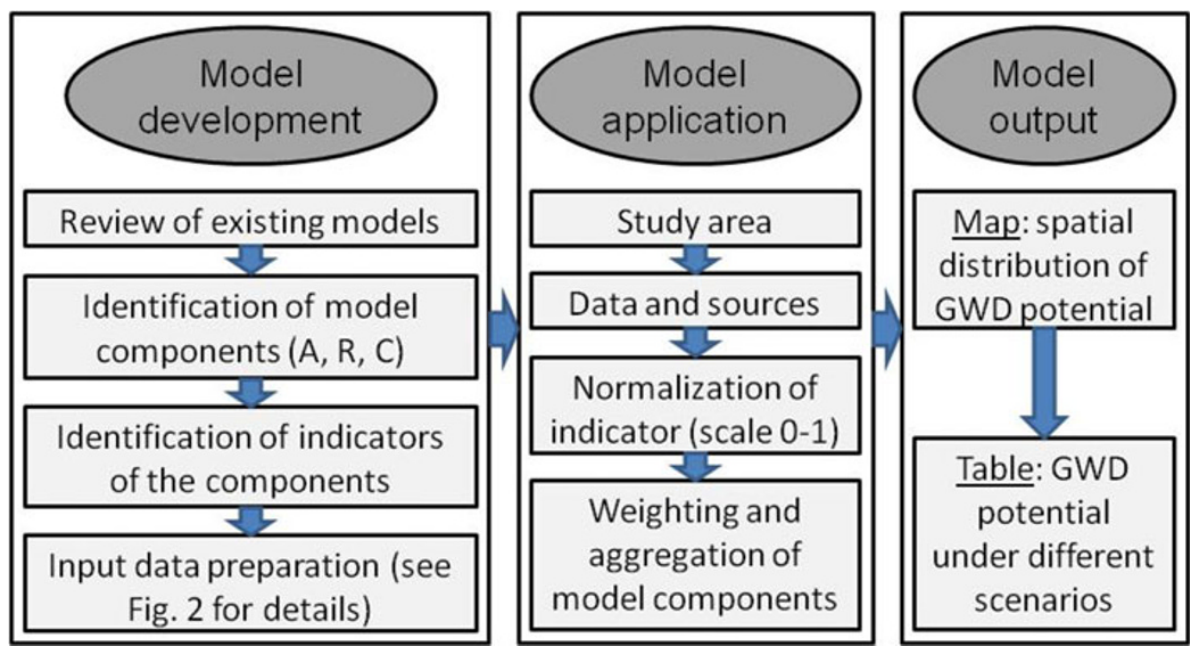

Fig. 2 Input data (indicator values) preparation technique

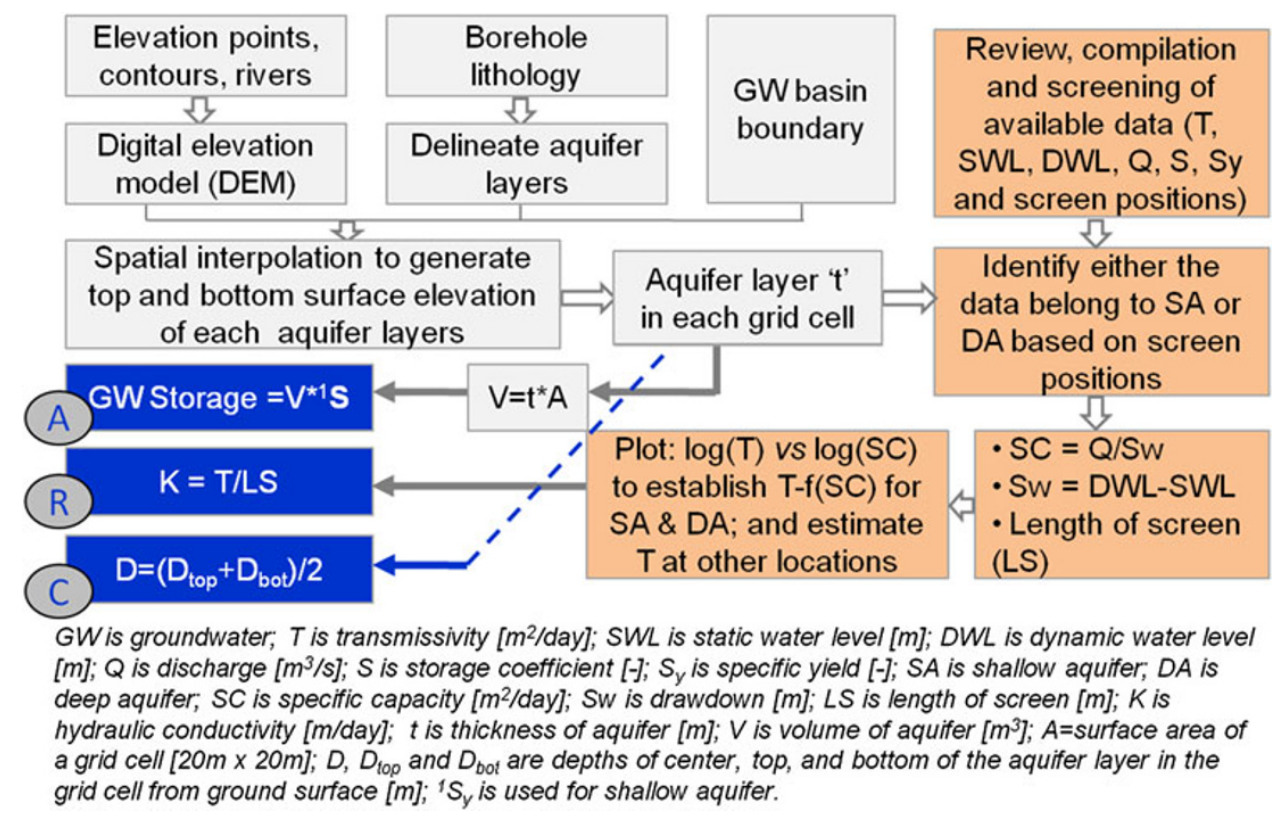

aquitard and deep aquifer layers before using it for spatial interpolation. From the perspective of groundwater storage estimation, thickness stands for the distance from an assumed upper limit of groundwater level to the top of the underlying layer. In this study, the upper limit of groundwater level is assumed at 0.5 meters below ground level (mbgl).

Storage coefficient ( $S$ ) (or $S_{\mathrm{y}}$ in case of shallow aquifer), on the other hand, refers to the storage and release ability of the aquifers. The $S$ describes the compressibility of the mineral skeleton of the aquifer matrix and the expansion of the water. The $S$ data in deep aquifer were taken from Pandey and Kazama (2011) and varied from 0.00023 to 0.07 . The S-raster was used in conjunction with thicknessraster to estimate groundwater storage volume in deep aquifer. The cell size of both the rasters was $20 \times 20 \mathrm{~m}$ and that of storage volume raster was also the same. For shallow aquifer, the $S_{\mathrm{y}}$ data were not available. In the absence of data, it was assumed as 0.20 throughout the shallow aquifer. One of the earlier studies (Acres International 2004) also has used this value.

Estimation of hydraulic conductivity $(K)$ Hydraulic conductivity refers to the capacity of an aquifer layer to transmit water through the medium and therefore can be used as an indicator of groundwater release potential of an aquifer. It can be calculated as a ratio of transmissivity $(T)$ and aquifer thickness. If the water wells in the study area are generally screened in the most productive intervals of the aquifers only, then aquifer thickness can be defined as the total length of screened interval (e.g., Mace et al. 2000). In this study, aquifer thickness is defined as the total 


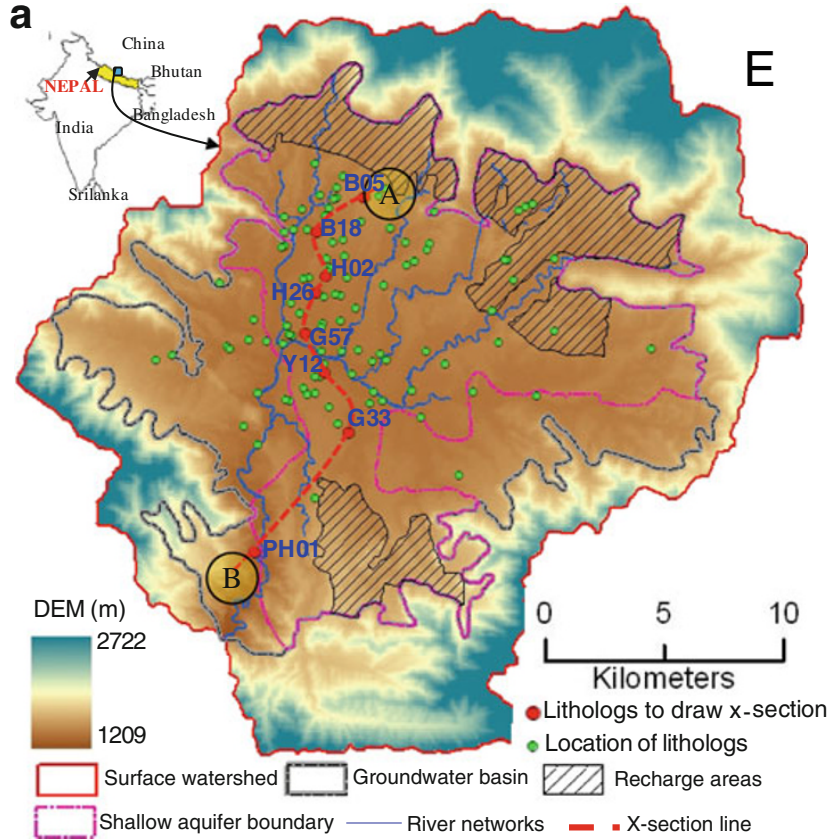

b
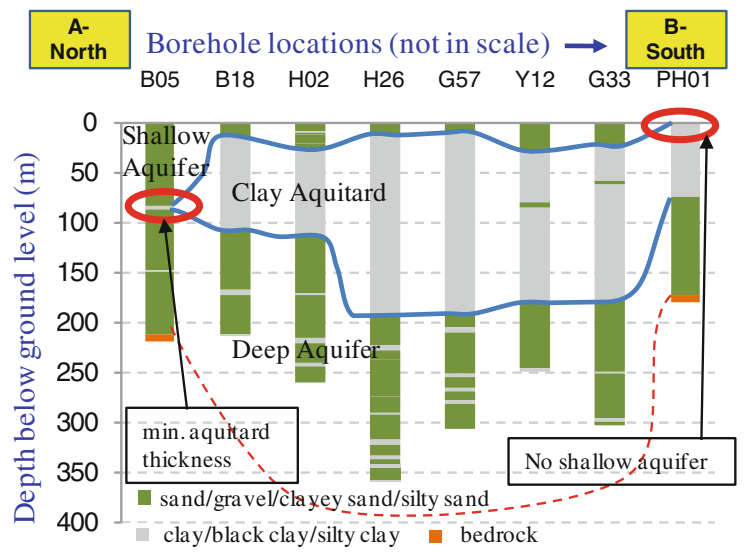

B05, B 18: Gongabu; H02: Lazimpat; H26: Durbarmarg;

G57: Tripureshwor; Y12: Patandhoka; G33: Satdobato; PH01: Pharping

Fig. 3 a Study area: Kathmandu Valley groundwater basin in central Nepal (data sources: groundwater basin boundary and recharge areas from JICA (Japan International Cooperation Agency) (1990); river networks from Department of Survey in Nepal; DEM from Jarvis et al. (2008); sources of lithologs are outlined in Table 1) b Northsouth cross-section along $A-B$ (Pandey and Kazama 2011)

length of screened interval in the well because water wells in the valley's aquifers are generally screened only in the most productive intervals of the aquifer (revealed by several borehole data collected from various sources). The $T$ values were estimated from specific capacity (SC, defined as discharge per unit drawdown) data using following empirical equations from Pandey and Kazama (2011): $T=0.8857(\mathrm{SC})^{1.1624}$ (for the shallow aquifer) and $T=1.1402$ (SC) ${ }^{1.0068}$ (for the deep aquifer), where units of $T$ and $\mathrm{SC}$ are in $\mathrm{m}^{2} /$ day.
Estimation of depth of center of aquifer layer below ground level (D) For each aquifer (shallow and deep aquifers), firstly, depth of top and bottom of aquifer below ground level (i.e., $D_{\text {top }}$ and $D_{\text {bot }}$ in Fig. 2) was calculated from aquifer thickness raster using ArcGIS. Then, arithmetic average of $D_{\text {top }}$ and $D_{\text {bot }}$ was used as an estimated $D$. Higher the value of $D$, higher would be the cost for groundwater extraction.

\section{Application of the model}

The model was applied in Kathmandu Valley groundwater basin as a case study site. Description of the study area, data sources and handling of input data are discussed in the following sub-sections. The sequence of the application procedure is depicted in Fig. 1.

\section{Study area}

The groundwater basin of Kathmandu Valley is has an altitude of $1,340 \mathrm{~m}$ above the mean sea level. It covers $327 \mathrm{~km}^{2}$ out of $664 \mathrm{~km}^{2}$ surface watershed area in central Nepal (Fig. 3a). The valley is characterized by warm and temperate climate in semi-tropics, and receives $80 \%$ of $1,755 \mathrm{~mm}$ annual rainfall during monsoon season (JuneSeptember) (Acres International 2004). The excess rainwater during rainy season could be stored in aquifers if their groundwater storage potentials are known. To estimate the storage potentials, information about aquifer layers and their spatial distribution within the groundwater basin is required. The aquifers in the valley consist of quaternary sediments and recent alluvium (Kharel et al. 1998) of lacustrine and fluvial origin up to 500-600 m thick in the central part of the basin. From the hydrogeologic perspective, the stratigraphy of the sediment deposits can be classified into three general hydrogeologic layers in descending order as shallow aquifer, aquitard, and deep aquifer (Fig. 3b). Thickness of the clay layer is more than $200 \mathrm{~m}$ in the central part and decreases gradually towards north and south-eastern part of the valley, which are probable recharge areas for the valley's deep aquifer (JICA 1990). In general, most of the recharge areas are confined in high flat plains and alluvial low plains. The aquifer material consists of lake deposits (gravel, sand, silt, clay, peat, and lignite) and fluvial deposits (boulder, gravel, sand, and silt) (Kharel et al. 1998). The mineral composition of the aquifer material is dominated by quartz, $\mathrm{K}$-feldspar, plagioclase, and mica with minor chlorite and calcite (Paudel et al. 2004).

The groundwater basin is home to 1.53 million people (population density is 4,690 person/ $/ \mathrm{km}^{2}$ ), $84.3 \%$ of them live in urban areas (Pandey et al. 2010). Groundwater is a 
major source of domestic water supply for those populations. Groundwater extraction has been continuously increasing since the 1970 s, with extraction exceeding recharge since the mid-1980s. This is mainly due to increase in population density from 3,150 to 4,690 persons/ $\mathrm{km}^{2}$ during 1991-2001 (Pandey et al. 2010). With no regulations on groundwater use and no management interventions, current status of achievements in sustainable groundwater management is relatively 'poor' (Pandey et al. 2011). Considering future growth in water demand and sustainable use of groundwater resources, it has become imperative to understand and map groundwater storage volumes and identify potential areas for groundwater development in the valley's aquifers.

\section{Data and sources}

Data and information were collected from several sources (Table 1). Verbal communications and discussion with prominent hydrogeologists working in the study area were also conducted to improve the delineation of the aquifer layers from borehole lithology.

\section{Normalization of the indicators}

All the three indicators representing the components of ARC model are different in units, range of the values and functional relationship with groundwater development potential. The differences have created a hurdle in aggregating the indicators together in its present form. To deal with the issue, all the indicators were normalized to a uniform scale before aggregating them to a composite index. The normalization was conducted based on the minimum and maximum value by rescaling the indicators up to 1.0 ; with 1.0 as the best value representing highest potential for groundwater development. For instance, for the indicators whose increments result in higher potential for groundwater development, the maxima are regarded as the best value and given 1.0 (i.e., $X_{i} / X_{\max }, i=$ indicator value at the $i$ th grid cell). Conversely, if the indicators decrease potential, the minima are given a value of 1.0 (i.e., $\left.X_{\min } / X_{i}\right)$. To deal with the possible influence of extreme values of the indicators in the analysis, 90- and 10-percentile values are considered as maxima and minima, respectively.

\section{Aggregation of the ARC model components}

The three components of the ARC model were aggregated in a form of a composite score with appropriate weights to the components. The weights were assigned based on the component's hierarchical importance with regard to groundwater development. For groundwater development, firstly, resource should be available in the soil matrix; secondly, the soil matrix should be able to release the available resources; and thirdly, the cost factor comes to play. Therefore, highest weight should be assigned to the component ' $A$ ', and then to ' $R$ ' and then to ' $C$ '. Further, to ascertain an acceptable weight maintaining the hierarchy, a scenario analysis was performed. Four scenarios with a hierarchical difference in the component weights as 5,10,15 and $20 \%$ were considered and percentage of area under three classes of the potentials (i.e., low, medium and high) for the scenarios were calculated. Though, the weights depend on preference of the authority responsible for groundwater management in the target area, results of the scenario analysis help decisionmaking process in that regard. In this paper, for the purpose of illustration of the ARC model, the hierarchical difference in the component weights of $5 \%$ is considered; i.e., weights to the A, R and C are assigned as 38.3, 33.3 and $28.4 \%$, respectively. Based on the aggregated/composite scores, potential areas for groundwater development were classified as high (score $>0.50)$, medium (score $=0.25-0.50$ ) and low (score $<0.25)$.

Table 1 Data and sources

\begin{tabular}{|c|c|c|}
\hline $\begin{array}{l}\text { S } \\
\text { no. }\end{array}$ & Data & Sources \\
\hline 1. & Borehole lithology & $\begin{array}{l}\text { Department of Mines and Geology, National Drilling } \\
\text { Company, Sagarmatha drilling company, Metcalf and } \\
\text { Eddy (2000), Acres International (2004), NISAKU drilling } \\
\text { company, JICA (Japan International Cooperation Agency) } \\
\text { (1990), Groundwater Development Project/Department of } \\
\text { Irrigation }\end{array}$ \\
\hline 2. & Groundwater basin boundary & $\begin{array}{l}\text { Digitized from JICA (Japan International Cooperation } \\
\text { Agency) (1990) }\end{array}$ \\
\hline 3. & $\begin{array}{l}\text { Elevation points, contours, river } \\
\text { networks }\end{array}$ & $\begin{array}{l}\text { Digital data from Department of Survey, Government of } \\
\text { Nepal }\end{array}$ \\
\hline 4. & $\begin{array}{l}\text { Transmissivity }(T) \text {, storage coefficient } \\
(S) \text { and specific yield }\end{array}$ & $\begin{array}{l}\text { Binnie and Partners (1973), Metcalf and Eddy (2000), } \\
\text { Pandey and Kazama (2011) }\end{array}$ \\
\hline
\end{tabular}


Model output

The outputs were presented in maps and tables. Spatial distributions of the potentials were shown in GIS-produced maps, while the potential under different scenarios were presented in a form of table.

\section{Results and discussion}

This section discusses spatial distribution in thickness, groundwater storage volumes, and potential areas for groundwater
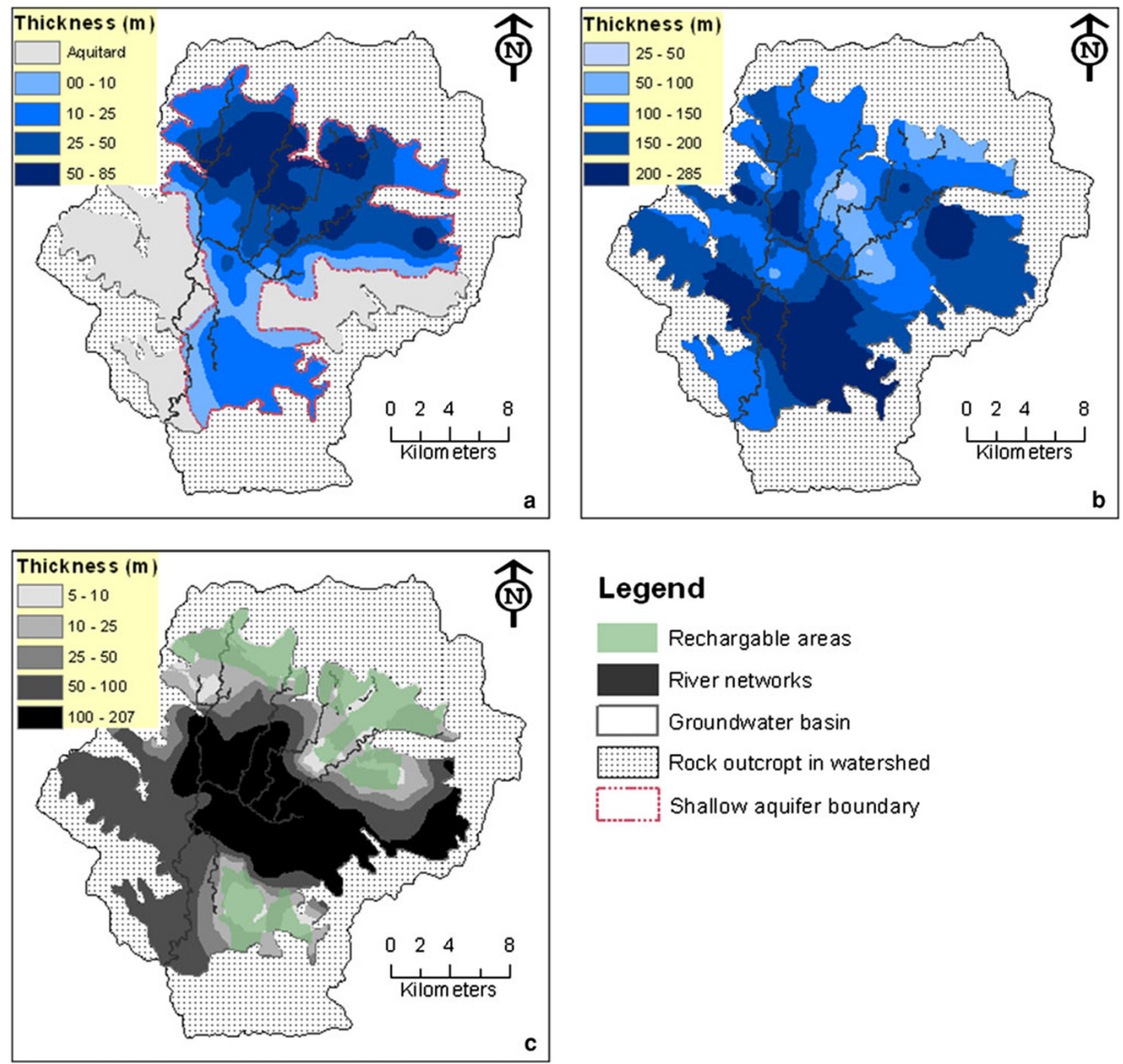

\section{Legend}

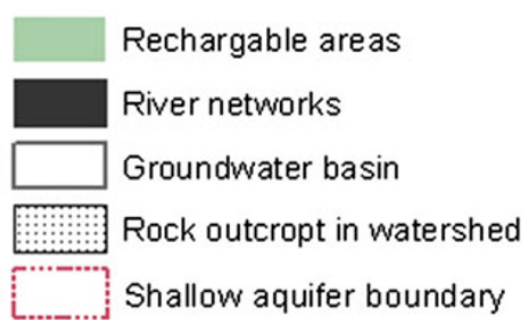

Fig. 4 Thickness distribution: a shallow aquifer, b deep aquifer, $\mathbf{c}$ aquitard. Recharge areas are shown in the aquitard layer to assist the discussion 

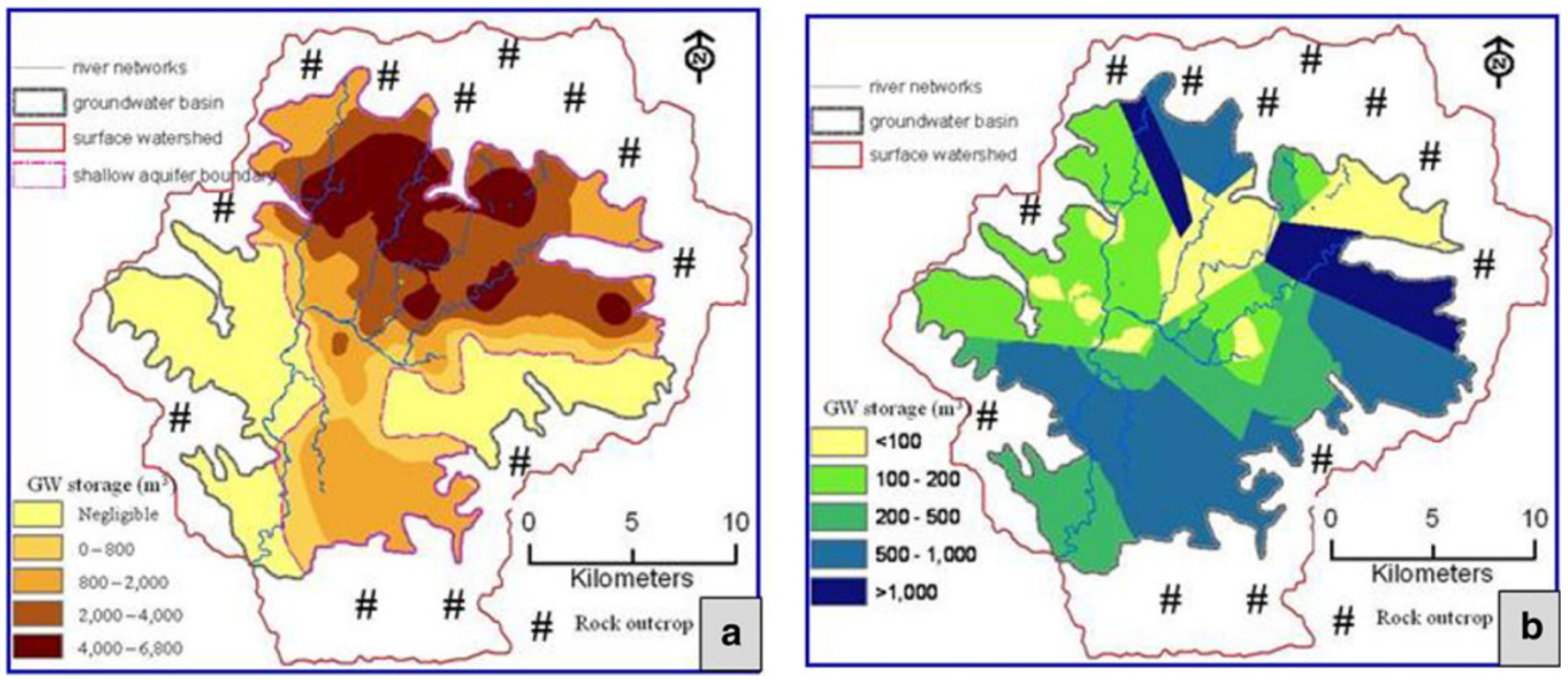

Fig. 5 Groundwater storage volume per $20 \times 20$ m pixel: a shallow aquifer, b deep aquifer

of the groundwater basin, however, perched aquifers which are not considered in this study, may exist in those areas. The shallow aquifer is thicker towards the northern part of the groundwater basin while the deep aquifer is thicker towards the southern part. The result on shallow aquifer is consistent with earlier reports that northern part has high percentage of aquifer units (KC 2003; Metcalf and Eddy 2000). The clay layer (i.e., aquitard) has minimum thickness $(<10 \mathrm{~m})$ towards northern and north-eastern part of the basin. Those areas are consistent with the potential recharge areas suggested by JICA (Japan International Cooperation Agency) (1990) (recharge areas are shown in Fig. 3a). The shallow aquifer surface extends over $241 \mathrm{~km}^{2}$ area, while aquitard and deep aquifers extend to the entire area of the groundwater basin (i.e., $327 \mathrm{~km}^{2}$ ). Total volumes of shallow and deep aquifers are estimated at 7,260 million cubic meters (MCM) and 56,813 MCM, respectively. For verifying the results earlier estimates were not available. So, an indirect approach was considered, in which, areas with minimum thickness in aquitard layer were compared with recharge areas of JICA (Japan International Cooperation Agency) (1990) (shown in Fig. 3a). The recharge areas were closely matched to the minimum thickness areas (Fig. 4c). This suggests that our estimate is reasonably acceptable.

\section{Distribution of groundwater storage volume}

Groundwater storage volumes in shallow and deep aquifers were estimated by multiplying aquifer volume with storage coefficient. The results show that shallow aquifer can store up to $6,800 \mathrm{~m}^{3} /$ pixel of groundwater volume, whereas most of the areas in deep aquifer can store only less than $1,000 \mathrm{~m}^{3} /$ pixel (Fig. 5). Over the entire area of shallow and deep aquifers, total groundwater storage volume is equal to 2,024 MCM (in shallow: 1,452 MCM; and in deep: 572 $\mathrm{MCM}$ ). In contrast to the aquifer volume, groundwater storage is high in shallow aquifer compared to the deep. It is mainly because of variation in storage characteristics in confined and unconfined conditions. For example, in this study, storage coefficient in deep aquifer varies from 0.00023 to 0.07 which is lower by few to several orders of magnitude compared to the storage coefficient in shallow aquifer (i.e., 0.20).

High storage volume per pixel $(20 \times 20 \mathrm{~m})$ as well as total over the entire shallow aquifer suggests the potential role of shallow aquifer for meeting the valley's water demand if it could be used as a major source for groundwater extraction and could be refilled by means of artificial or managed aquifer recharge. However, analysis for cost and benefit should be carried out separately before deciding to launch such recharge projects. If we continue using Kathmandu Valley's groundwater reserve at the same rate as in 2001, i.e., 21.56 MCM/year (as discussed in Pandey et al. 2010), shallow and deep aquifers in the valley will be emptied in less than 100 years (without considering recharge). The analysis based on estimated storage volume and rate of extraction is consistent with that of Cresswell et al. (2001) based on recharge and extraction rates.

Distribution of hydraulic conductivity $(K)$

The estimated $K$ range from 12.5 to $44.3 \mathrm{~m} /$ day (mean $=$ 28.7 ) in shallow and 0.32 to $8.78 \mathrm{~m} /$ day (mean $=4.5$ ) in the deep aquifer, whereas transmissivity $(T)$ range from 163 to $1,256 \mathrm{~m}^{2} /$ day in shallow aquifer and 21.2 to $737 \mathrm{~m}^{2} /$ day in deep aquifer (see Appendix). Relatively wide range of the $T$ suggests some degree of heterogeneity in aquifer structure; 

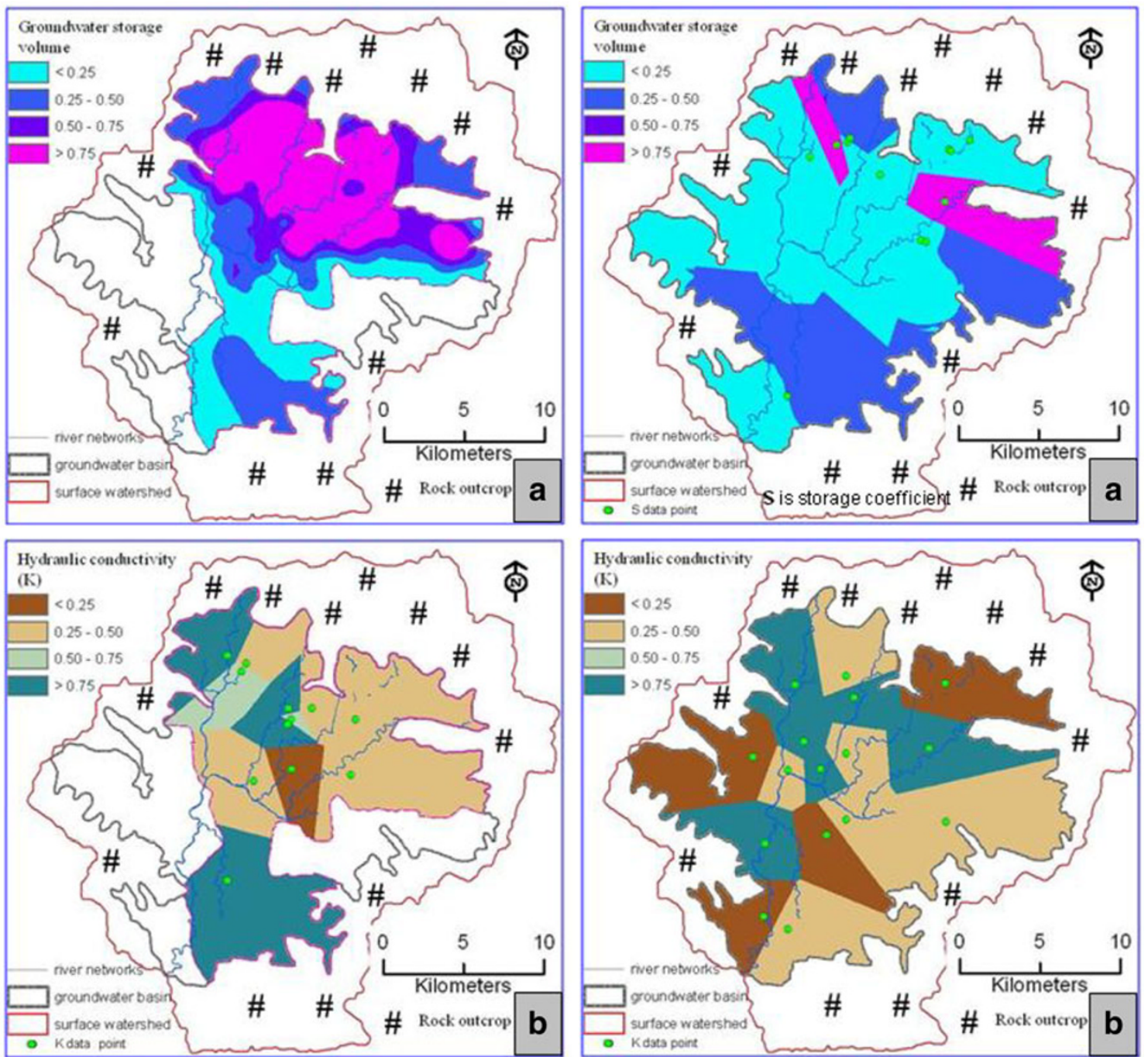

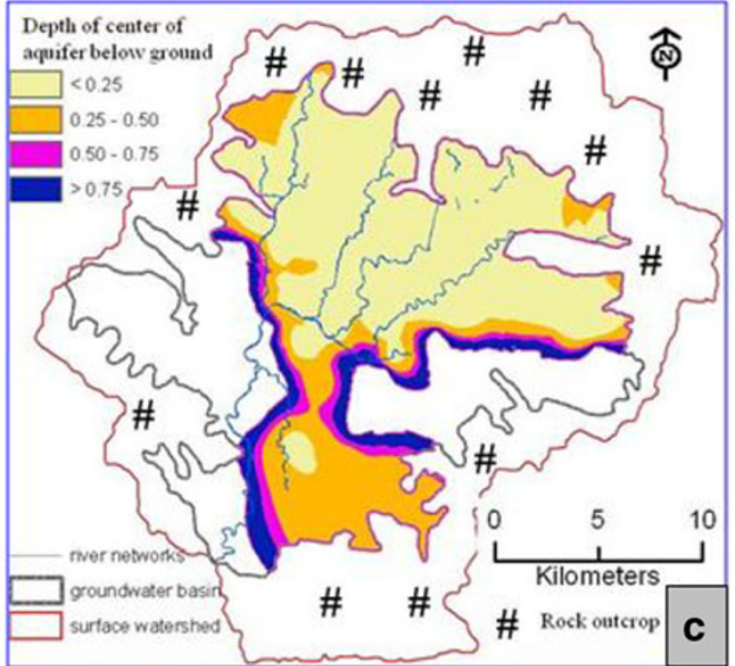

Shallow Aquifer

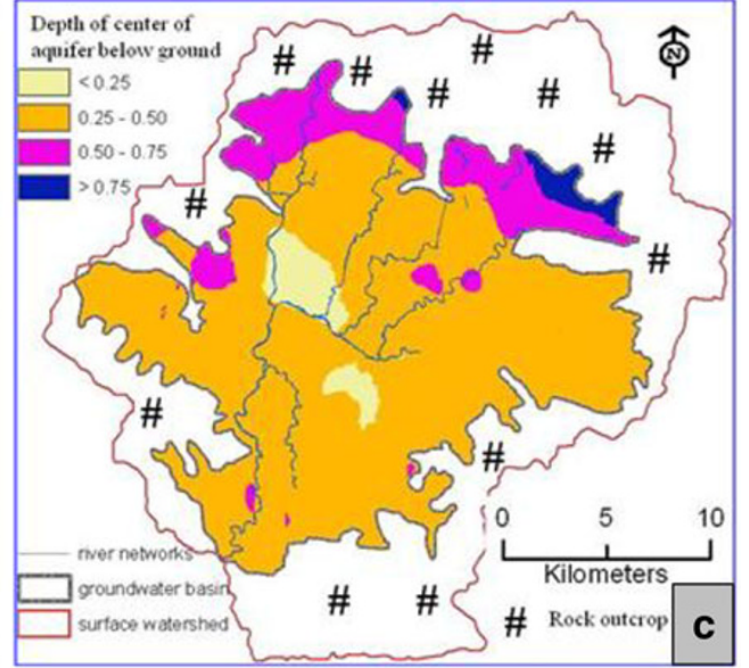

Deep Aquifer

Fig. 6 Normalized indicator values: a groundwater storage volume, b hydraulic conductivity, c depth of center of aquifer below ground level. $\mathrm{mbgl}$ is meter below ground level 
which corresponds to significant differences in hydraulic conductivity and thickness of water-bearing sediments. The estimate of hydraulic conductivity in deep aquifer is in good agreement with values reported in Metcalf and Eddy (2000) for deep aquifer (i.e., $0.51-8.16 \mathrm{~m} /$ day).

Potential areas for groundwater development

Potential areas for groundwater development are classified as low or medium or high based on an aggregated score of the

Table 2 Weights to ARC model components under four scenarios

Components Weights with hierarchical difference in component weight by

\begin{tabular}{lllll} 
& $5 \%$ & $10 \%$ & $15 \%$ & $20 \%$ \\
\hline $\mathrm{A}$ & 38.3 & 43.3 & 48.3 & 53.3 \\
$\mathrm{R}$ & 33.3 & 33.3 & 33.3 & 33.3 \\
$\mathrm{C}$ & 28.4 & 23.4 & 18.4 & 13.4 \\
\hline
\end{tabular}

ARC model components. In this study, each components of the ARC model are represented by a single indicator; therefore, aggregation of the indicators is equivalent to aggregation of the components. Before the aggregation, the indicators were normalized to a scale of $0-1$ as described in the "Materials and methods" section. The normalized indicator values in shallow and deep aquifers are shown in Fig. 6. The scenario analysis under different weights (weights are shown in Table 2) shows that percentage of areas under different groundwater development potential classes varies with weight (Table 3). In the real world, the selection of the groundwater development areas may be influenced by the preference of the authority responsible for that. Therefore, for assisting the authority in making decisions, results with different scenarios of weights are calculated and presented in Table 3. For the purpose of illustrating the ARC model in this study, potential areas with the hierarchical difference in the component weights of $5 \%$ (i.e., weights to the A, R and $\mathrm{C}$ as 38.3, 33.3 and $28.4 \%$, respectively) are shown in Fig. 7. It suggests that high potential areas are located towards

Table 3 Area (\%) under three development potential classes under four scenarios

\begin{tabular}{|c|c|c|c|c|c|c|c|c|}
\hline \multirow[t]{3}{*}{ Groundwater development potential } & \multicolumn{8}{|c|}{ Area $(\%)$ with hierarchical difference in component weight by } \\
\hline & \multicolumn{4}{|c|}{ Shallow aquifer } & \multicolumn{4}{|c|}{ Deep aquifer } \\
\hline & $5 \%$ & $10 \%$ & $15 \%$ & $20 \%$ & $5 \%$ & $10 \%$ & $15 \%$ & $20 \%$ \\
\hline Low (score $<0.25$ ) & 0.0 & 0.0 & 0.0 & 0.0 & 20.7 & 26.6 & 31.2 & 32.5 \\
\hline Medium (score $0.25-0.50$ ) & 51.1 & 43.1 & 36.7 & 42.0 & 64.1 & 59.9 & 57.6 & 56.3 \\
\hline High $($ score $>0.50)$ & 48.9 & 56.9 & 63.3 & 58.0 & 15.2 & 13.5 & 11.2 & 11.2 \\
\hline
\end{tabular}

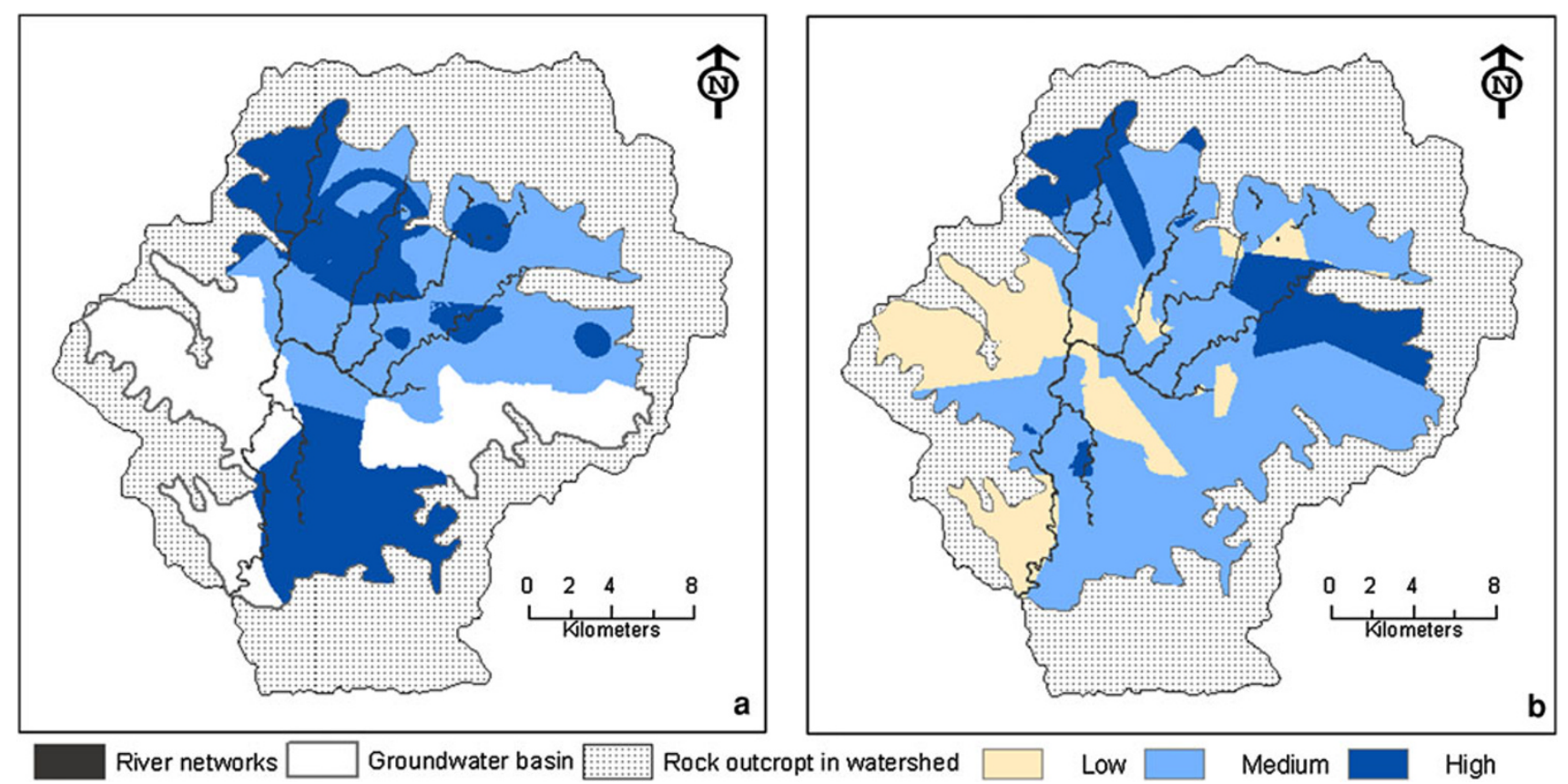

Fig. 7 Groundwater development potential: a shallow aquifer, b deep aquifer 
northern and southern parts in shallow aquifer and north-east and north-west parts in deep aquifer. Medium potential areas cover more than half of the total aquifer areas and are located toward central part in shallow aquifer and central and southern part in deep aquifer.

\section{Summary and conclusion}

In the context of increasing depletion in groundwater resources, mainly because of excessive extraction without adequately knowing groundwater resource availability and distribution, this paper discusses a GIS-based approach to estimate spatial distribution in groundwater storage volume and proposes a GIS-based ARC model to delineate potential areas for groundwater development. It further illustrates the approach with a case study of groundwater aquifers in the Kathmandu Valley where groundwater management is yet to begin.

Results show that shallow aquifer has high storage volume per pixel (as high as $\sim 6,800 \mathrm{~m}^{3} /$ pixel compared to less than $1,000 \mathrm{~m}^{3} /$ pixel in major parts of deep aquifer) as wells as total over the entire shallow aquifer (total = 1,452.25 MCM) and has huge potential to store water in the empty space in between current and assumed upper limit of the groundwater level. If the groundwater reserve is used at the same rate as in 2001 (i.e., 21.56 MCM/year), the reserve would be emptied in less than 100 years. On the other hand, if the shallow aquifer could be managed properly (by regulation of groundwater development as well as augmentation of recharge), it has potential to meet most of the water demand in the valley. The estimates of groundwater storage volume in this study, however, should be considered as a preliminary one but still very useful for planning purpose). The estimate could be improved by considering dynamics of groundwater flow and recharge characteristics which can be estimated through three-dimensional modeling of groundwater system, but the approach, of course, is resource-intensive. Also, considering one more indicator"depth of water level" - for C would improve the model results as this indicator is equally important as "depth of aquifer" to workout the cost of groundwater extraction.
Results in this paper show prospects for shallow aquifer recharge. Apart from that, high potential areas for groundwater development suggested by ARC model are located towards northern and southern parts in shallow aquifer and north-east and north-west parts in deep aquifer. Such results have implications in planning future groundwater extraction activities.

The model can be applied to other areas and regions of the world as the three components can accommodate most of the hydrogeologic characteristics relevant to the delineation. However, depending upon the data availability and priority of the authority responsible for groundwater development and management, indicators and their numbers for the components may vary. For example, estimates of groundwater storage volume could be improved by considering dynamics of groundwater flow and recharge characteristics, which can be achieved through three-dimensional numerical modeling of the groundwater system. In addition, for the further improvement of the ARC model, recharge characteristics and water quality could be considered as indicators of the 'A'; storage coefficient or other aquifer/soil properties could be considered as additional indicators of the ' $\mathrm{R}$ '; and cost for transporting the pumped water to the consumption site could also be added as an indicator of the ' $\mathrm{C}$ '.

Acknowledgments The authors would like to acknowledge GCOE Program of University of Yamanashi for supporting this study; and several organizations in Nepal (e.g. Groundwater Research and Development Project/Department of Irrigation, Melamchi Drinking Water Supply Project-Kathmandu, CEMAT Consulting Company, NISAKU drilling company-branch office Kathmandu, National drilling company-Kathmandu, Sagarmatha drilling company, Department of Mines and Geology-Kathmandu, Integrated Rural Development Services Nepal) for kindly providing data and information.

Open Access This article is distributed under the terms of the Creative Commons Attribution License which permits any use, distribution, and reproduction in any medium, provided the original author(s) and the source are credited.

\section{Appendix}

See Tables 4 and 5 .

Table 4 Transmissivity $(T)$ and hydraulic conductivity $(K)$ values at fifty wells in deep aquifer

\begin{tabular}{clllrllllll}
\hline S no. & Well ID & Well name & Location & Date & XP $(\mathrm{m})$ & YP $(\mathrm{m})$ & SC $\left(\mathrm{m}^{2} /\right.$ day $)$ & $\mathrm{LS}(\mathrm{m})$ & $\mathrm{T}\left(\mathrm{m}^{2} / \mathrm{day}\right)$ & $\mathrm{K}(\mathrm{m} / \mathrm{day})$ \\
\hline 1 & B04 & JI1 & Bansbari & 1989 & 632,613 & $3,070,640$ & 71.9 & 36 & 84.4 & 2.34 \\
2 & B08 & ME06 & Gongabu & 1985 & 630,564 & $3,070,149$ & 453.0 & 99 & 538.4 & 5.44 \\
3 & B11 & ME08 & Gongabu & 1985 & 630,396 & $3,069,613$ & 619.0 & 139 & 737.3 & 5.30 \\
4 & B12 & ME09 & Gongabu & 1998 & 630,417 & $3,069,835$ & 529.9 & 72 & 630.5 & 8.76 \\
5 & B14 & ME10 & Balaju/Bypass & - & 630,077 & $3,069,112$ & 80.9 & 43 & 95.0 & 2.21 \\
6 & B16 & ND01 & NWSC, Gongabu & 1905 & 629,444 & $3,070,115$ & 359.6 & 57 & 426.8 & 7.49 \\
\hline
\end{tabular}


Table 4 continued

\begin{tabular}{|c|c|c|c|c|c|c|c|c|c|c|}
\hline S no. & Well ID & Well name & Location & Date & XP (m) & YP (m) & $\mathrm{SC}\left(\mathrm{m}^{2} /\right.$ day $)$ & LS (m) & $\mathrm{T}\left(\mathrm{m}^{2} /\right.$ day $)$ & $\mathrm{K}$ (m/day) \\
\hline 8 & BH6 & ME12 & Bhaktapur & 1985 & 638,206 & $3,064,948$ & 421.1 & 56 & 500.2 & 8.73 \\
\hline 9 & G10 & ME21 & Police HQ, Naxal & 1997 & 631,311 & $3,067,142$ & 37.8 & 49 & 44.2 & 0.90 \\
\hline 10 & G13 & ME22 & Nepal Rastra Bank, Baluwatar & 1998 & 631,211 & $3,068,131$ & 108.0 & 30 & 127.1 & 4.24 \\
\hline 11 & G18 & ND03 & Royal Drug, Thapathali & 1905 & 631,113 & $3,064,162$ & 54.0 & 42 & 63.2 & 1.51 \\
\hline 12 & G20 & ME23 & S.R. Tropical Hospital, Teku & 1997 & 628,990 & $3,064,801$ & - & 60 & 127.0 & 2.12 \\
\hline 13 & G21 & ND04 & Maternity Hospital, Thapathali & 1905 & 630,226 & $3,064,123$ & 131.3 & 42 & 154.8 & 3.69 \\
\hline 14 & G22 & ME24 & Rastriya Banijya Bank, Bhadrakali & 1998 & 630,491 & $3,065,068$ & 106.8 & 70 & 125.7 & 1.80 \\
\hline 15 & G24 & ME25 & Nepal Television, Singh Durbar & 1998 & 631,042 & $3,064,872$ & 62.4 & 60 & 73.2 & 1.22 \\
\hline 16 & G31 & ND06 & Himal Cement, Chobar & 1905 & 627,580 & $3,060,261$ & 113.0 & 30 & 133.0 & 4.43 \\
\hline 17 & G33 & ME26 & Swimming Pool, Satdobato & 1997 & 631,389 & $3,060,756$ & 41.5 & 60 & 48.5 & 0.81 \\
\hline 18 & G34 & ME27 & Dasarath Stadium, Tripureshwor & 1998 & 630,006 & $3,064,771$ & 164.6 & 43 & 194.3 & 4.52 \\
\hline 19 & G35 & ME28 & DWIDP, Hariharbhawan, Pulchowk & 1994 & 630,130 & $3,062,924$ & 18.2 & 90 & 21.2 & 0.32 \\
\hline 20 & G36 & ND07 & Nardevi hospital, Naradevi & 1905 & 628,980 & $3,066,161$ & 73.4 & 36 & 86.2 & 2.39 \\
\hline 21 & GK5 & ME33 & Nayapati VDC-4 & 1985 & 638,776 & $3,070,183$ & 76.3 & 88 & 89.5 & 1.02 \\
\hline 22 & H02 & ND11 & Hotel Shankar, Lazimpat & 1905 & 630,463 & $3,067,301$ & 53.4 & 33 & 62.6 & 1.90 \\
\hline 23 & H07 & ND12 & Hotel Kathmandu, Maharajgunj & 1905 & 631,162 & $3,068,839$ & 153.9 & 30 & 181.6 & 6.05 \\
\hline 24 & $\mathrm{H} 26$ & ND14 & Hotel D’ Annapurna, Durbarmarga & 1905 & 630,010 & $3,066,582$ & 280.9 & 58 & 332.8 & 5.74 \\
\hline 25 & $\mathrm{H} 29$ & ME36 & Hotel dwarika, Battishputali & 1997 & 632,608 & $3,065,813$ & 108.0 & 48 & 127.1 & 2.65 \\
\hline 26 & $\mathrm{H} 30$ & ME37 & Royal Singi Hotel, Lal Durbar & 1996 & 630,339 & $3,066,490$ & 116.6 & 32 & 137.3 & 4.29 \\
\hline 28 & H69 & ND15 & Hotel Aquamarine, Minbhawan & 1905 & 632,664 & $3,064,011$ & 101.4 & 30 & 119.3 & 3.98 \\
\hline 29 & M05 & AI2 & Duwakot VDC-4 Bhaktapur & 1997 & 640,000 & $3,065,000$ & 149.3 & 24 & 176.2 & 7.34 \\
\hline 30 & MH6 & ME42 & Mulpani VDC-4 & 1997 & 637,772 & $3,066,170$ & 329.3 & 115 & 390.6 & 3.40 \\
\hline 31 & $\mathrm{P} 03$ & ME45 & Bishal Bazar, New Road & 1997 & 629,384 & $3,065,758$ & 259.2 & 59 & 306.9 & 5.20 \\
\hline 32 & P34 & ND20 & Marbari Dharmik, Kamalpokhari & 1905 & 631,032 & $3,066,456$ & 51.5 & 30 & 60.4 & 2.01 \\
\hline 33 & P47 & ME46 & My Shop, Putalisadak & 1992 & 630,568 & $3,065,225$ & 66.7 & 49 & 78.2 & 1.60 \\
\hline 34 & $\mathrm{PH} 2$ & ME47 & Pharping, Setidevi VDC-6 & 1997 & 627,487 & $3,055,706$ & 83.1 & 98 & 97.7 & 1.00 \\
\hline 35 & $\mathrm{PH} 3$ & ME48 & Bungmati VDC-9 & 1977 & 628,993 & $3,054,932$ & 64.3 & 37 & 75.4 & 2.04 \\
\hline 36 & $\mathrm{X} 01$ & ND23 & Indian Pension C., Thamel & 1986 & 629,510 & $3,067,166$ & 131.4 & 42 & 154.8 & 3.69 \\
\hline 37 & X03 & ND25 & Pranesh Sharma, Mandikatar & 1995 & 633110 & $3,069,313$ & 165.4 & 43 & 195.3 & 4.54 \\
\hline 38 & X07 & ND29 & Danida, Lainchaur & 1990 & 630,775 & $3,067,943$ & 207.1 & 42 & 244.8 & 5.83 \\
\hline 39 & X09 & ND31 & Embassy Japan - E, Panipokhari & 1995 & 630,764 & $3,068,430$ & 194.4 & 36 & 229.7 & 6.38 \\
\hline 40 & $\mathrm{X} 10$ & ND32 & HRH PrinceesXhauni & 1996 & 626,833 & $3,065,593$ & 19.5 & 72 & 22.7 & 0.32 \\
\hline 41 & Xll & ND33 & U.S. AID Mission, Ravibhawan & 1998 & 627,432 & $3,064,733$ & 32.0 & 50 & 37.4 & 0.75 \\
\hline 42 & $\mathrm{X} 12$ & ND34 & Hem Electronics, Sitapaila & 1999 & 625,626 & $3,066,986$ & 28.9 & 72 & 33.7 & 0.47 \\
\hline 43 & $\mathrm{X} 13$ & ND35 & Pashupati, Gausala & 2000 & 632,741 & $3,066,258$ & 53.2 & 36 & 62.3 & 1.73 \\
\hline 44 & $\mathrm{X} 15$ & ND37 & Baluwa Udhyog, Mulpani & 2003 & 638,190 & $3,067,253$ & 174.5 & 45 & 206.1 & 4.58 \\
\hline 45 & $\mathrm{X} 16$ & ND38 & Nisaku Yard, Imadol & 1994 & 632,615 & $3,061,683$ & 63.8 & 29 & 74.9 & 2.58 \\
\hline 46 & $\mathrm{X} 17$ & ND39 & PV Array, Bode & 1994 & 637,570 & $3,064,686$ & 19.4 & 48 & 22.6 & 0.47 \\
\hline 47 & X19 & ND41 & Katunje Water Supply, Katunje & 2002 & 638,828 & $3,061,565$ & 62.0 & 36 & 72.7 & 2.02 \\
\hline 48 & $\mathrm{X} 20$ & ND42 & HISEF Finance, Hattisar & 2001 & 630,887 & $3,066,587$ & 261.8 & 42 & 310.0 & 7.38 \\
\hline 49 & $\mathrm{X} 21$ & ND43 & Hem Trading, Ganabahal & 1987 & 629,063 & $3,065,285$ & 168.5 & 30 & 198.9 & 6.63 \\
\hline 50 & $\mathrm{X} 22$ & ND44 & Patan Hospital, Lagankhel & 1994 & 630,403 & $3,061,775$ & 19.8 & & & \\
\hline
\end{tabular}

$K(\mathrm{~m} /$ day $): \min =0.32, \max =23.0$, mean $=4.5$

Specific capacity (SC) and length of screen (LS) were taken from Pandey and Kazama (2011); $T=1.1402(\mathrm{SC})^{1.0068} ; K=T / \mathrm{LS} ; T$ for G20 was taken from Metcalf and Eddy (2000). XP, YP is the location in Modified UTM coordinate system; $S C$ specific capacity, $L S$ length of screen 
Table 5 Transmissivity $(T)$ and hydraulic conductivity $(K)$ values at 15 wells in shallow aquifer

\begin{tabular}{|c|c|c|c|c|c|c|c|c|c|c|}
\hline S no. & Well ID & Well name & Location & Date & $\mathrm{XP}(\mathrm{m})$ & YP (m) & $\mathrm{SC}\left(\mathrm{m}^{2} /\right.$ day $)$ & LS (m) & $T\left(\mathrm{~m}^{2} /\right.$ day $)$ & $K(\mathrm{~m} /$ day $)$ \\
\hline 1 & B06 & ME04 & Gongabu & 1984 & 631,156 & $3,071,464$ & 276.3 & 25 & 609.8 & 24.39 \\
\hline 2 & B07 & ME05 & Gongabu & 1997 & 630,878 & $3,070,980$ & 140.3 & 22 & 277.3 & 12.61 \\
\hline 3 & $\mathrm{BH} 2$ & ME11 & Bode & 1984 & 637,652 & $3,064,512$ & 151.6 & 17 & 303.4 & 17.85 \\
\hline 4 & D05 & ME16 & Dhobikhola & 1984 & 634,655 & $3,068,371$ & 615.9 & 35 & $1,548.0$ & 44.23 \\
\hline 5 & D06 & ME17 & Kapan VDC-9 & 1984 & 633,776 & $3,068,701$ & 244.5 & 15 & 529.0 & 35.26 \\
\hline 6 & D09 & ME18 & Mahankal Chaur-6 & 1984 & 633,946 & $3,067,986$ & 819.1 & 52 & $2,156.5$ & 41.47 \\
\hline 7 & D10 & ME19 & Kapan VDC-3 & 1984 & 633,745 & $3,067,704$ & 269.8 & 15 & 593.2 & 39.55 \\
\hline 8 & G39 & ND08 & Tribhuvan Int'l Airport & 1905 & 634,004 & $3,064,905$ & 88.9 & 13 & 163.2 & 12.55 \\
\hline 9 & M02 & All & Sunakothi, Ward No-1, Lalitpur & 1997 & 630,000 & $3,058,000$ & 193.2 & 12 & 402.3 & 33.52 \\
\hline 10 & M08 & AI5 & Phutung VDC Ward No-5 & 1993 & 630,000 & $3,072,000$ & 443.4 & 24 & $1,056.6$ & 44.03 \\
\hline 11 & P36 & ND21 & L. M. Suvir brother, Gokarna & 1905 & 637,934 & $3,067,975$ & 290.9 & 25 & 647.4 & 25.90 \\
\hline 12 & WHOl & BP1 & Baudhatinchuli & 1971 & 635,218 & $3,068,680$ & 235.0 & 18 & 505.1 & 28.06 \\
\hline 13 & WH05 & BP4 & Bode & 1972 & 637,337 & $3,064,618$ & 137.0 & 20 & 269.8 & 13.49 \\
\hline 14 & WH06 & BP5 & Gokarna & 1972 & 637,276 & $3,068,951$ & 113.0 & 14 & 215.7 & 15.40 \\
\hline 15 & $\mathrm{X} 14$ & ND36 & Mr. Nunkaranji (2), Baneswor & 2002 & 631,612 & $3,064,149$ & 508.2 & 30 & $1,238.3$ & 41.28 \\
\hline
\end{tabular}

$K(\mathrm{~m} /$ day $): \min =12.5, \max =44.3$, mean $=28.7$

Specific capacity (SC) and length of screen (LS) were taken from Pandey and Kazama (2011); $T=0.8857$ (SC) ${ }^{1.1624} ; K=T / \mathrm{LS} ; T$ for WHO1 was taken from Binnie and Partners (1973). XP, YP is the location in modified UTM coordinate system; $S C$ specific capacity, $L S$ length of screen

\section{References}

Acres International (2004) Final report of optimizing water use in Kathmandu Valley (ADB-TA) project. Submitted to Government of Nepal, Ministry of Physical Planning and Works, Acres International in association with Arcadis Euroconsult Land and Water Product Management Group, East Consult (P) Ltd. \& Water Asia (P) Ltd

Akbar TA, Lin H, DeGroote J (2011) Development and evaluation of GIS-based ArcPRZM-3 system for spatial modelling of groundwater vulnerability to pesticide contamination. Comput Geosci 37(7):822-830

Babikar IS, Mohamed MAA, Hiyama T, Kato K (2005) A GIS based drastic model for assessing aquifer vulnerability in Kakamighara heights, Gifu Prefecture, Central Japan. Sci Total Environ 345:127-140

Binnie \& Partners (1973) Groundwater Investigations, Kathmandu water supply and sewerage scheme. A report submitted to the Government of Nepal.

Bouwer H (2002) Artificial recharge of groundwater: hydrogeology and engineering. Hydrogeology 10(1):121-142

Chenini I, Mammou AB (2010) Groundwater recharge study in arid region: an approach using GIS techniques and numerical modelling. Comput Geosci 36(6):801-817

Cresswell RG, Bauld J, Jacobson G, Khadka MS, Jha MG, Shrestha MP, Regmi S (2001) A first estimate of ground water ages for the deep aquifer of the Kathmandu Basin, Nepal, using the radioisotope chlorine-36. Ground Water 39(3):449-457

Dillon PJ (2005) Future management of aquifer recharge. Hydrogeology 13(1):313-316

Jaiswal RK, Mukherjee S, Krishnamurthy J, Saxena R (2003) Role of remote sensing and GIS techniques for generation of groundwater prospect zones towards rural development: an approach. Int J Remote Sens 24(5):993-1008

Jarvis A, Reuter HI, Nelson A, Guevara E (2008) Hole-filled SRTM for the globe Version 4, available from the CGIAR-CSI SRTM $90 \mathrm{~m}$. http://srtm.csi.cgiar.org
JICA (Japan International Cooperation Agency) (1990) Groundwater Management Project in Kathmandu Valley, Final report Main report and supporting reports, November 1990

Johnson TA, Njuguna WM (2002) Aquifer storage calculation using GIS and MODFLOW, Los Angeles County, California. In: ESRI user conference proceedings, San Diego, USA

Jorcin P (2006) GIS for aquifer monitoring and modeling-from field surveys to simulation models: a case study of Kaluvelly Pondicherry basin, South India. In: Proceedings of 5th international conference on geographic information technology and application, MAP ASIA 2006, 28 August-01 September, Bangkok

Kattaa B, Al-Fares W, Al Charideh AR (2010) Groundwater vulnerability assessment for the Banyas Catchment of the Syrian coastal area using GIS and the RISKE method. J Environ Manage 91(5):1103-1110

KC K (2003) Optimizing Water use in Kathmandu Valley (ADB TA3700), Final Draft Report on Groundwater/Hydrogeology in Kathmandu Valley, Jan 2003

Kendy E, Molden D J, Steenhuis T S, Liu C (2003) Policies drain the North China Plain: Agricultural policy and groundwater depletion in Luancheng County, 1949-2000. International Water Management Institute Research Report, no. 71

Kharel BD, Shrestha NR, Khadka MS, Singh VK, Piya B, Bhandari R, Shrestha MP, Jha MG, Munstermann D (1998) Hydrogeological conditions and potential barrier sediments in the Kathmandu Valley. Final Report of the Technical cooperation project-Environment Geology, between Kingdom of Nepal, HMG and Federal Republic of Germany

Konikow LF, Kendy E (2005) Groundwater depletion: a global problem. Hydrogeology 13(1):317-320

Krishnamurthy J, Venkates K, Jayaraman V, Manivel M (1996) An approach to demarcate groundwater potential zones through remote sensing and geographic information system. Int J Remote Sens 17(10): 1867-1884

Kumar MD, Patel A, Ravindranath R, Singh OP (2008) Chasing a mirage: water harvesting and artificial recharge in naturally 
water-scarce regions. Economic and Political Weekly August 30, 2008

Mace RE, Smyth RC, Xu L, Liang J (2000) Transmissivity, hydraulic conductivity, and storativity of the Carrioz-Wilcox aquifer in Texas. A technical report prepared for Texas Water Development Board. Bureau of Economy and Geology, The University of Texas at Austin, Texas

Metcalf and Eddy (2000) Urban water supply reforms in the Kathmandu Valley (ADB TA Number 2998-NEP). Completion report, vol I and II, executive summary, main report and Annex 1 through 7. Metcalf and Eddy, Inc. with CEMAT Consultants Ltd., 18 Feb 2000

Mills WR (2002) The quest for water through artificial recharge and wastewater recycling. In: Dillon PG (eds) Management of aquifer recharge for sustainability, pp 3-10, Balkema Publishers

Murthy KSR (2000) Groundwater potential in a semi-arid region of Andhra Pradesh—a geographical information system approach. Int J Remote Sens 21(9):1867-1884

Nobre RCM, Filho OCR, Mansur WJ, Nobre MMM, Cosenza CAN (2007) Groundwater vulnerability and risk mapping using GIS, modelling and a fuzzy logic tool. J Contam Hydrol 94(3-4): 277-292

Pandey VP, Kazama F (2011) Hydro-geologic characteristics of groundwater aquifers in Kathmandu Valley-Nepal. Environ Earth Sci 62(8):1723-1732

Pandey VP, Chapagain SK, Kazama F (2010) Evaluation of groundwater environment of Kathmandu Valley. Environ Earth Sci 60(6):1329-1342

Pandey VP, Shrestha S, Chapagain SK, Kazama F (2011) A framework for measuring groundwater sustainability. Environ Sci Policy 14(4):396-407

Pathak DR, Hiratsuka A, Awata I, Chen L (2009) Groundwater vulnerability assessment in shallow aquifer of Kathmandu Valley using GIS-based DRASTIC model. Environ Geol 57(7): 1569-1578

Paudel MR, Kuwahara Y, Sakai H (2004) Changes in mineral composition and depositional environment recorded in the present and past basin-fill sediments of the Kathmandu Valley, central Nepal. Himalayan J Sci 2(4):222-223

Puranik SC, Salokhe SV (2006) Delineating groundwater potential areas based on bore well characters in Kodoli Basin, Panhala
Taluka, Kolhapur district, Maharashtra. In: Rajan S, Pandey PC (eds) Antarctic geoscience, ocean-atmosphere interaction and paleoclimatology, pp 307-317. National Centre for Antarctic and Ocean Research (NCAOR), Goa, India

Ravi Shankar MN, Mohan G (2006) Assessment of groundwater potential and quality in Bhatsa and Kalu river basins of Thane district, western Deccan volcanic province of India. Environ Geol 49(7):990-998

Reddy VR (2005) Costs of resource depletion externalities: a study of groundwater overexploitation in Andhra Pradesh, India. Environ Dev Econ 10(4):533-556

Saha D, Upadhyay S, Dhar YR, Singh R (2007) The aquifer system and evaluation of its hydraulic parameters in parts of South Ganga Plain, Bihar, India. J Geol Soc India 69:1031-1041

Saha D, Dhar YR, Vittala SS (2010) Delineation of groundwater development potential maps in parts of marginal Ganga Alluvial Plain in South Bihar, Eastern India. Environ Monit Assess 165(1-4):179-191

Scanlon BR, Healy RW, Cook PG (2002) Choosing appropriate techniques for quantifying groundwater recharge. Hydrogeology 10(1):18-39

Shah T, Molden D, Sakthivadivel R, Seckler D (2000) The global groundwater situation: overview of opportunities and challenges. International Water Management Institute, Colombo

Shrinivasa Rao Y, Jugran DK (2003) Delineation of groundwater potential zones and zones of groundwater quality suitable for domestic purpose using remote sensing and GIS. Hydrol Sci J 48(5):821-833

Singh AK, Prakash SR (2002) An integrated approach of remote sensing, geophysics and GIS to evaluation of groundwater potentiality of Ojhala Sub-watershed, Mirzapur District, UP, India. Conference paper, Asian Conference on GIS, GPS, Aerial Photography and Remote Sensing, Bangkok-Thailand

Tuinhof A, Heederik JP (eds) (2003) Management of aquifer recharge and subsurface storage. Netherlands National Committee International Association of Hydrogeology, no. 4. NNC-IAH Publication

Wahyuni S, Oishi S, Sunada K (2008) The estimation of the groundwater storage and its distribution in Uzbekistan. Ann J Hydraulic Eng 52:31-36 